\title{
最適性規準法を用いた位相最適化におけるフィルタリング法 FILTERING METHOD FOR TOPOLOGY OPTIMIZATION ANALYSIS USING OPTIMALITY CRITERIA METHOD
}

\author{
藤井大地*, 鈴木 克幸**, 大坪英臣*** \\ Daiji FUJII, Katsuyuki SUZUKI and Hideomi OHTSUBO
}

\begin{abstract}
In the topology optimization analysis based on the homogenization design method or the density approach, the checkerboards, that is the formation of regions of alternating solid and void elements ordered in a checkerboard-like fashion, often appear in the optimum solutions. Therefore, the filtering method is necessary for these approaches. In this paper, we present an effective filtering method for the topology optimization analysis using the optimality criteria method as optimizer. In this method, the value of the gravity control function is controlled as a constrained condition. The gravity control function, which was presented by the author in the topology optimization analysis using the SLP method ${ }^{9 / 10)}$, is defined from the relations of the density of an element with that of its neighbor elements. This function imposes the penalty in the checkerboards and the gray scale density, that is, if the function is high, the checkerboards and gray scales disappear in the optimum solution. In this paper, this filtering method is applied in the topology optimization using the homogenization design method and the density approach. Several examples of 2D and 3D problems are shown to demonstrated the effectiveness of the present method.
\end{abstract}

Keywords: Filtering method, Topology optimization, Optimality criteria method, Homogenization method, Density approach フィルタリング法, 位相最適化, 最適性規準法, 均質化法, 密度法

\section{1.はじめに}

連続体の位相最適化技術は，機械分野においてはすでに実務レ ベルで利用され，部品の軽量化等で実績が得られつつある。建築 分野においても, 研究レベルでは, 大森らによる GA を利用した トラス構造の位相最適化 ${ }^{1)}$, ESO 法による位相最適化 ${ }^{2), 3)}$, 本間ら によるセル・オートマトンを利用した位相最適化 ${ }^{4), 5}$ 等の研究が行 われている。一方, 欧米では, Ramm と Maute らを中心にシェル 構造の位相最適化 ${ }^{6}$, 橋梁の位相最適化, 鉄筋コンクリートの鉄 筋の位相最適化等 ${ }^{7} の$ 現実的な問題一の適用が試みられている。 これらの研究の多くは, 部材の断面設計を中心とするいわゆる構 造設計よりも設計の第一段階であるコンセプトデザインへの利用 を目指すものであり，このような技術が建築デザインの新しいッ 一ルとなる可能性を秘めている。

このような背景にもとづいて，著者らもグランドストラクチャ 一法による骨組構造の位相最適化 ${ }^{8)}$, 均質化設計法による板・シ エル構造の位相最適化 ${ }^{9), 10), 11)}$, 密度法による 3 次元構造の位相最 適化手法 ${ }^{12)}$ を示し，これらの手法をもとに建築デザインに利用で きる位相最適化ツールの開発を目指している。

ところで,このような手法をツール化する上で問題となるのが，
数学的な最適解が必ずしも設計者が期待するようなシンプルで明 解な位相とはならないという点である。また, 連続体の位相最適 化では, ソリッド要素と空隙要素がチェッカーボードのように交 互に並ぶ数值的不安定現象が多く見られ，実際にどのように構造 物の境界を定めるべきかを判断しにくい場合が多い。このような 問題を解決する方法としては, 一つには, Maute and Ramm ら ${ }^{13)}$ が提案しているように, 均質化設計法と同様の手法で位相を求め, それにもとづいて有限要素メッシュを再分割し，さらに位相を求 めるというようなことを繰り返すアダプティブ法的な手法が考え られる。このようにして得られた位相は滑らかな境界を持ち非常 に明解なものとなっているが，計算コストと開発コストがかかり すぎるという問題がある。他の方法としては, 均質化設計法や密 度法による位相最適化手法にフィルタリング法を組み合わせるこ とが考えられる。このようなフィルタリング法に関しては文献 14) に整理されており, 著者らも文献 9),10)に新しいフィルタリング法 を提案している。

著者らが提案したフィルタリング法は，一つの要素の周辺の密 度に注目し，その要素が中実であれば周辺に中実要素が, その要 素が空隙であれば周辺に空隙が集中するような関数を定義する。

\footnotetext{
* 東京大学:工学系研究科 助手・博士 (工学)
}

** 東京大学新領域創成科学研究科 助教授 $\cdot$ Ph. D. *** 東京大学工学系研究科 教授・工博
Research Assoc., Graduate School of Engineering, The University of Tokyo, Dr. Eng.

Assoc. Prof., Graduate School of Frontier Sciences, The University of Tokyo, Ph. D. Prof., Graduate School of Engineering, The University of Tokyo, Dr. Eng. 
そしてこの関数をすべての要素について加えた関数（重力制御 関数）を制御することで，チェッカーボードのない明解な位相を 求める方法である。文献9),10)では, 2 次元問題の均質化設計法で, この方法と SLP 法を組み合わせる手法を示し良好な結果を得てい る。しかしながら, 制約条件が質量のみの剛性最大化問題では, SLP 法よりも最適性規準法 (Optimality criteria method) の方が計算 効率上有利である。したがって, 本方法と最適性規淮法との組み 合わせを検討する必要がある。また，このフィルタリング法を 3 次元問題に適用した場合の効果についても検討する必要がある。

そこで, 本論文では, 重力制御関数值を制約条件とする位相最 適化問題を最適性規淮法を用いて解く方法を示し，このような方 法により, 2 次元および 3 次元問題において, チェッカーボード 状の密度分布がなく, 設計者に明確な情報を与える位相が求めら れることを示す。 2 次元問題の位相最適化手法としては, 設計領 域を多孔質材料とし, 材料のミク口構造の穴の大きさと角度を設 計変数とする均質化設計法 9),10),15),16)を用いる。3 次元問題では, 計 算効率上の理由から均質化設計法を簡略化し, 各要素の弾性定数 を要素密度のべき乗関数に比例すると仮定する密度法 ${ }^{12), 17), 18), 19) を ~}$ 用いる。なお，文献 12)においても最適性規淮法を用いているが， この場合は重力制御関数を文献 9),10) と同様に目的関数に付加し た形で用いており，本論文に示す方法とその点で異なる。

以下，本論文第 2 章では，均質化設計法による 2 次元構造物の 位相最適化問題を，重力制御関数値を制約条件として最適性規淮 法で解く方法を示す。第 3 章では, 密度法による 3 次元の位相最 適化問題を同様な方法で解く方法を示す。第 4 章では, 第 2 章, 第 3 章で示した方法の有効性を 2 次元および 3 次元の解析例題で 示す。第 5 章では以上のまとめを述べる。

\section{2. 均質化設計法による 2 次元問題の位相最適化}

\section{1 最適化問題の定式化}

均質化設計法では, 図 1 に示すように設計領域を有限要素分割 し，各要素の材料が，異なる長方形の穴を有するセルが周期的に 並ぶミク口構造を有するものとする。そして, 各要素のミクロ構 造の穴の大きさ $a, b$ と角度 $\theta$ を設計変数として, 材料の必要なと ころでは穴が小さく，必要でないところでは穴が大きくなること を利用して構造物の最適位相を求める。剛性の最大化を目的と寸 る場合の本方法の最適化問題は次式のように定式化される ${ }^{9), 16)}$

$$
\begin{aligned}
& \min _{\alpha \in \mathbf{L}}\left[\mathbf{d}^{r} \mathbf{K d}\right] \\
& \mathbf{L}=\left\{\alpha \mid 0 \leq \alpha_{i} \leq 1 \quad(i=1, \cdots, 2 N), \quad \sum_{i=1}^{N}\left(1-a_{i} b_{i}\right) \leq m_{s}\right\}
\end{aligned}
$$

ここに， $\alpha$ は設計変数 $\left\{a_{1}, a_{2}, \cdots, a_{N}, b_{1}, b_{2}, \cdots, b_{N}\right\}$ で, $a_{i}, b_{i}$ は $i$ 番目 要素のミク口構造の穴の大きさを表し， $N$ は有限要素数である。 なお，ミクロ構造の穴の角度は各要素の応力の主軸方向に向ける ものとして設計変数からは除外する ${ }^{16)}$ 。また，(1)式の $\mathbf{d}$ は節点変 位ベクトル，Kは全体剛性マトリックス，Lは与えられた条件を 満たす許容設計変数の集合， $m_{S}$ は質量（ここでは総密度比）の制 約值である。なお，(1)式の $\mathbf{d}^{T} \mathbf{K d}$ は外力の仕事量である平均コン プライアンスを示しており，次式にように表しておく。

$$
C(\alpha)=\mathbf{d}^{T} \mathbf{K d}
$$

場合が多いため, 位相境界をはっきりさせる働きを持つ次式の重 力制御関数を定義する ${ }^{9), 10}$ 。

$$
G(\alpha)=\sum_{i=1}^{N} g_{i}(\alpha) / \sum_{i=1}^{N} m_{i}
$$

ここに,

$$
g_{i}=\sum_{j=1}^{m_{i}}\left[\rho_{i} \rho_{j}+\left(1-\rho_{i}\right)\left(1-\rho_{j}\right)\right]
$$

ただし， $\rho_{i}=1-a_{i} b_{i}$ であり, $m_{i}$ は $i$ 番目の要素と辺を共有する要 素で, 内部の要素では 4, 端や隅の要素ではそれ以下となる。ま た，(3)式の $G$ は， $0<G \leq 1$ となる。

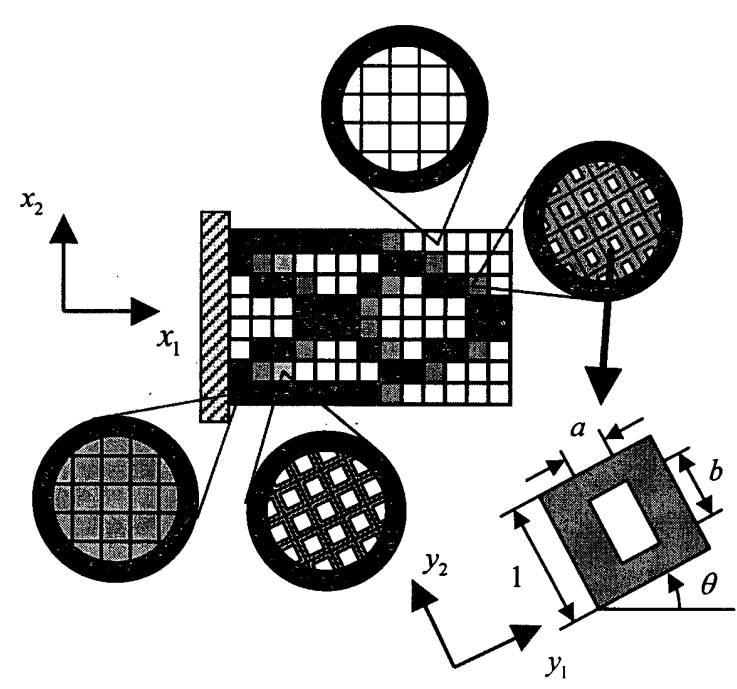

図 1 均質化設計法による位相最適化

図 2 は, 密度比 $\rho$ が $1,0.5,0$ となる場合について, (4)式の関数 $g_{i}$ の值を示したものである。図からわかるように,この関数值は, $i$ 番目要素が黒で周辺要素が白の場合，または $i$ 番目要素が白で周 辺要素が黒の場合が最も低い值となる。チェッカーボード状の解 はこのパターンに相当するので，この関数值が高くなればチェッ カーボードは防げる。また, この関数の特徴として, グレースケ ール（密度比が 0.5 の場合）にもペナルティーが課され，すべて グレーの值は，すべて黒またはすべて白よりも低い值となる。し たがって，(3)式の関数值が高くなれば，チェッカーボード状の密 度分布が少なくしかも白黒のはっきりした位相が得られる。

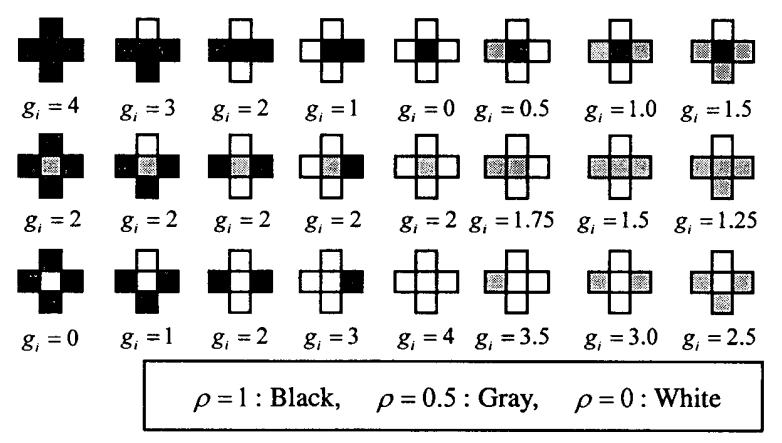

図 $2 i$ 番目要素とその近隣要素の密度比と関数 $g_{i}$ の関保

(1)式を解いて得られる最適位相では位相の境界がはっきりしない 
そこで,ここでは, (3)式の $G$ を与えられた值以上にする制約を課 すことにする。この場合，(1)式は次のように書ける。 $\min _{\alpha \in \mathrm{L}}[C(\alpha)]$

$\mathbf{L}=\left\{\alpha \mid 0 \leq \alpha_{i} \leq 1 \quad(i=1, \cdots, 2 N), \quad \sum_{i=1}^{N}\left(1-a_{i} b_{i}\right) \leq m_{s}, \quad G \geq \bar{G}\right\}$

ここに, $\bar{G}$ は重力制御関数の制約值で, $0 \leq \bar{G} \leq 1$ の範囲で与える。

\section{2 最適性規準法による解法}

(5)式の問題を最適性規淮法によって解く ${ }^{16)}$ 。最適性規淮法では， (5)式の問題を解くために次式の Lagrangian を定義する。

$$
L(\alpha)=C(\alpha)-\Lambda\left(\sum_{i=1}^{N}\left(1-a_{i} b_{i}\right)-m_{s}\right)-\Lambda_{g}(\bar{G}-G(\alpha))
$$

ただし， $\Lambda, \Lambda_{g}$ はラグランジェ乗数 $\left(\Lambda \leq 0, \Lambda_{g} \leq 0\right)$ であり, ラグ ランジェ乗数がかかる項は制約条件を満足すれば負になる。そし て，(6)式を設計変数とラグランジェ乗数に関して変分をとること により，最適性規準を求める。この場合は次式となる。

$$
\begin{aligned}
\delta L(\alpha) & =\sum_{i=1}^{N}\left(\frac{\partial C(\alpha)}{\partial a_{i}}+b_{i} \Lambda+\frac{\partial G(\alpha)}{\partial a_{i}} \Lambda_{g}\right) \delta a_{i} \\
& +\sum_{i=1}^{N}\left(\frac{\partial C(\alpha)}{\partial b_{i}}+a_{i} \Lambda+\frac{\partial G(\alpha)}{\partial b_{i}} \Lambda_{g}\right) \delta b_{i} \\
& -\left(\sum_{i=1}^{N}\left(1-a_{i} b_{i}\right)-m_{S}\right) \delta \Lambda-(\bar{G}-G(\alpha)) \delta \Lambda_{g}=0
\end{aligned}
$$

(7)式は(6)式の最小化の条件である。(7)式より， $\delta a_{i}, \delta b_{i}(i=1, \cdots, N)$ ， $\delta \Lambda, \delta \Lambda_{g}$ の任意性から次式が成り立つ。

$$
\begin{array}{cc}
-\frac{b_{i} \Lambda+\frac{\partial G(\alpha)}{\partial a_{i}} \Lambda_{g}}{\frac{\partial C(\alpha)}{\partial a_{i}}}=1 & -\frac{a_{i} \Lambda+\frac{\partial G(\alpha)}{\partial b_{i}} \Lambda_{g}}{\frac{\partial C(\alpha)}{\partial b_{i}}}=1 \\
\frac{1}{m_{s}} \sum_{i=1}^{N}\left(1-a_{i} b_{i}\right)=1 & \frac{\bar{G}}{G(\alpha)}=1
\end{array}
$$

(8)式より次のような関係式を作ることができる。

$$
\begin{aligned}
& -\frac{b_{i} \Lambda+\frac{\partial G(\alpha)}{\partial a_{i}} \Lambda_{g}}{\frac{\partial C(\alpha)}{\partial a_{i}}}=1 \Rightarrow-\frac{b_{i} \Lambda+\frac{\partial G(\alpha)}{\partial a_{i}} \Lambda_{g}}{\frac{\partial C(\alpha)}{\partial a_{i}}}=\frac{a_{i}}{a_{i}} \\
& \Rightarrow a_{i}^{(k+1)}=\left[-\frac{b_{i}^{(k)} \Lambda^{(k)}+\frac{\partial G\left(\alpha^{(k)}\right)}{\partial a_{i}^{(k)}} \Lambda_{g}^{(k)}}{\frac{\partial C\left(\alpha^{(k)}\right)}{\partial a_{i}^{(k)}}}\right]^{\beta} a_{i}^{(k)} \quad(i=1, \cdots, N)
\end{aligned}
$$

ここに, $\beta$ は設計変数の更新幅を制御するべき乗係数である。(12) 式と同様の操作により，次式のような関倸式が得られる。

$$
\begin{aligned}
& b_{i}^{(k+1)}=\left[-\frac{a_{i}^{(k)} \Lambda^{(k)}+\frac{\partial G\left(\alpha^{(k)}\right)}{\partial b_{i}^{(k)}} \Lambda_{g}^{(k)}}{\left.\frac{\partial C\left(\alpha^{(k)}\right)}{\partial b_{i}^{(k)}}\right]^{\beta} b_{i}^{(k)} \quad(i=1, \cdots, N)}\right. \\
& \Lambda^{(k+1)}=\left[\frac{1}{m_{S}} \sum_{i=1}^{N}\left(1-a_{i}^{(k)} b_{i}^{(k)}\right)\right]^{\beta} \Lambda^{(k)} \\
& \Lambda_{g}^{(k+1)}=\left[\frac{\bar{G}}{G\left(\alpha^{(k)}\right)}\right]^{\beta} \Lambda_{g}^{(k)}
\end{aligned}
$$

ただし， $a_{i}, b_{i}, \Lambda, \Lambda_{g}$ には次式の制約条件があるので,
$0 \leq a_{i} \leq 1, \quad 0 \leq b_{i} \leq 1 \quad(i=1, \cdots, N), \quad \Lambda \leq 0, \quad \Lambda_{g} \leq 0$ (12) (15)式より, 次式の最適性条件が得られる。

$$
\begin{aligned}
& a_{i}^{(k+1)}=\min \left\{\max \left\{0, s_{a i}^{(k)}\right\}, 1\right\} \\
& b_{i}^{(k+1)}=\min \left\{\max \left\{0, s_{b i}^{(k)}\right\}, 1\right\} \\
& \Lambda^{(k+1)}=\min \left\{0,\left[\frac{1}{m_{s}} \sum_{i=1}^{N}\left(1-a_{i}^{(k)} b_{i}^{(k)}\right)\right]^{\beta} \Lambda^{(k)}\right\} \\
& \Lambda_{g}^{(k+1)}=\min \left\{0,\left[\frac{\bar{G}}{G\left(\alpha^{(k)}\right)}\right]^{\beta} \Lambda_{g}^{(k)}\right\}
\end{aligned}
$$

ここに,

$$
\begin{aligned}
& s_{a i}^{(k)}=\left[-\frac{b_{i}^{(k)} \Lambda^{(k)}+\frac{\partial G\left(\alpha^{(k)}\right)}{\partial a_{i}^{(k)}} \Lambda_{g}^{(k)}}{\frac{\partial C\left(\alpha^{(k)}\right)}{\partial a_{i}^{(k)}}}\right]^{\beta} a_{i}^{(k)} \\
& s_{b i}^{(k)}=\left[-\frac{a_{i}^{(k)} \Lambda^{(k)}+\frac{\partial G\left(\alpha^{(k)}\right)}{\partial b_{i}^{(k)}} \Lambda_{g}^{(k)}}{\frac{\partial C\left(\alpha^{(k)}\right)}{\partial b_{i}^{(k)}}}\right]^{\beta} b_{i}^{(k)}
\end{aligned}
$$

(17),(18)式には, さらに設計変数の変動幅の制約（move limit）を 課す。この変動幅の制約は次のように書ける ${ }^{16)}$ 。

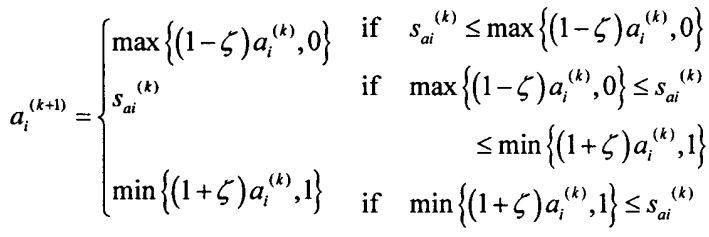

$$
\begin{aligned}
& b_{i}^{(k+1)}=\left\{\begin{array}{lrrr}
\max \left\{(1-\zeta) b_{i}{ }^{(k)}, 0\right\} & \text { if } & s_{b i}{ }^{(k)} \leq \max \left\{(1-\zeta) b_{i}{ }^{(k)}, 0\right\} \\
s_{b i}{ }^{(k)} & \text { if } & \max \left\{(1-\zeta) b_{i}^{(k)}, 0\right\} \leq s_{b i}{ }^{(k)} \\
& & & \leq \min \left\{(1+\zeta) b_{i}^{(k)}, 1\right\} \\
\min \left\{(1+\zeta) b_{i}^{(k)}, 1\right\} & & \text { if } & \min \left\{(1+\zeta) b_{i}^{(k)}, 1\right\} \leq s_{b i}{ }^{(k)}
\end{array}\right.
\end{aligned}
$$

ここに，「は変動幅の制約值 (move limit) である。

さらに, $\Lambda, \Lambda_{g}$ は最適化繰返し計算の各ステップの内側のループ

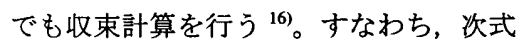

$$
\begin{aligned}
& s_{a i}^{(k+1)}=\left[-\frac{b_{i}^{(k)} \Lambda^{(k+1)}+\frac{\partial G\left(\alpha^{(k)}\right)}{\partial a_{i}^{(k)}} \Lambda_{g}^{(k+1)}}{\frac{\partial C\left(\alpha^{(k)}\right)}{\partial a_{i}^{(k)}}}\right]^{\beta} a_{i}^{(k)} \\
& s_{b i}^{(k+1)}=\left[-\frac{a_{i}^{(k)} \Lambda^{(k+1)}+\frac{\partial G\left(\alpha^{(k)}\right)}{\partial b_{i}^{(k)}} \Lambda_{g}^{(k+1)}}{\frac{\partial C\left(\alpha^{(k)}\right)}{\partial b_{i}^{(k)}}}\right]^{\beta} b_{i}^{(k)}
\end{aligned}
$$

から，(23),(24)式により設計変数を更新し，これから(19),(20)式に より $\Lambda, \Lambda_{g}$ を再度更新する。これを(25),(26)式に代入し，(23),(24) 式によりまた設計変数を更新するというようなループを繰り返す。 ただしこの間(25),(26)式の $a_{i}^{(k)}, b_{i}^{(k)}$ は更新しない。 
以上の計算の流れをまとめると, (23),(24)式で前ステップの解か ら設計変数の值を更新し,これから(19),(20)式によってラグランジ エ末定保数を更新する。そして，(25),(26)式を用いた内側のループ により，制約条件を満足するようにさらに設計変数の更新を行う。 これを次ステップの設計変数として, 平均コンプライアンス, 質 量（総密度比）を計算し, 感度保数を求め, 再び(23),(24)式によっ て設計変数を更新する。このような手続きを与えられたステップ 数まで繰り返す。

なお, (21)式中の平均コンプライアンス $C$ の設計変数 $a_{i}$ 関する 感度係数は次式のようにして求められる。

$$
\frac{\partial C}{\partial a_{i}}=\frac{\partial\left(\mathbf{d}^{T} \mathbf{K d}\right)}{\partial a_{i}}=\mathbf{d}^{T} \frac{\partial \mathbf{K}}{\partial a_{i}} \mathbf{d}-2 \mathbf{d}^{T} \mathbf{K} \frac{\partial \mathbf{d}}{\partial a_{i}}
$$

ただし，変位ベクトル $\mathbf{d}$ は次式の剛性方程式

$$
\mathbf{K d}=\mathbf{f}
$$

解であるから，(28)式の両辺を設計変数 $a_{i}$ で偏微分すると，

$$
\mathbf{K} \frac{\partial \mathbf{d}}{\partial a_{i}}=-\frac{\partial \mathbf{K}}{\partial a_{i}} \mathbf{d}
$$

となるので, これを(27)式に代入すると次式となる。

$$
\frac{\partial C}{\partial a_{i}}=-\mathbf{d}^{T} \frac{\partial \mathbf{K}}{\partial a_{i}} \mathbf{d}=-\mathbf{d}^{e i^{T}} \frac{\partial \mathbf{K}^{e i}}{\partial a_{i}} \mathbf{d}^{e i}=-\mathbf{d}^{e i}\left(\int_{\Omega^{i}} \mathbf{B}^{T} \frac{\partial \mathbf{D}^{H}}{\partial a_{i}} \mathbf{B} d \Omega^{e i}\right) \mathbf{d}^{e i}
$$

ここに， $\quad \mathbf{K}^{e i}, \mathbf{d}^{e i}$ は $i$ 番目要素の要素剛性マトリックスと節点変位 ベクトル, $\mathrm{B}$ は $i$ 番目要素のひずみー変位関係マトリックス, $\mathrm{D}^{H}$ は均質化法によって求められる均質化弹性マトリックス, $\Omega^{e i}$ は $i$ 番目要素の領域を表す。なお， $\mathbf{D}^{H}$ に関してはミク口構造の穴の 大きさ $a, b$ に関するデータベースをあらかじめ作成しておき，設 計変数に対する感度係数はその補間関数を微分することによって 求める。なお，本論文では文献 9) と同じデータベースを用いる ( $a, b$ に関して $51 \times 51$ 点の $\mathbf{D}^{H}$ を計算したデータベース)。

\section{3. 密度法による 3 次元問題の位相最適化}

\section{1 最適化問題の定式化}

密度法 ${ }^{12), 17,18), 19}$ は，材料の弾性剛性が密度比のべき乗に比例す ると仮定し, 図 3 に示すように各有限要素の密度比を設計変数と して最適位相を求める方法である。これは, 均質化設計法の穴の 大きさを $a=b$ として材料の等方性を仮定したものに対応する。

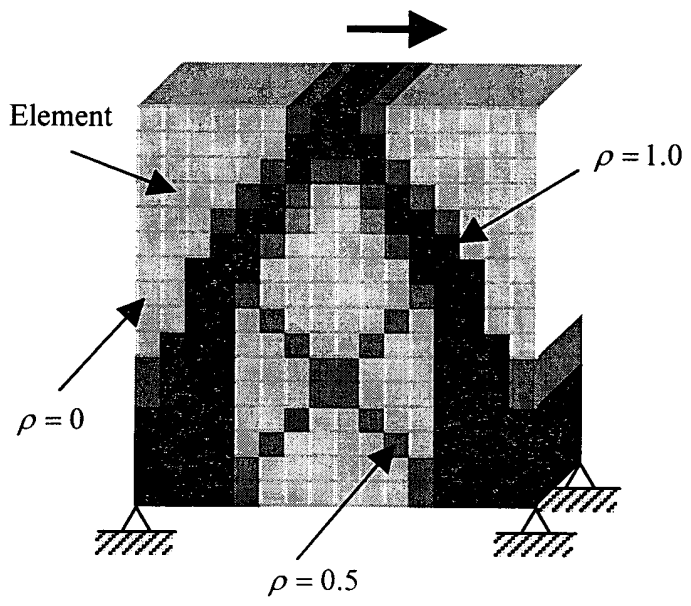

図 3 密度法による位相最適化
(5)式と同様に, 密度法による構造物の位相最適化問題は次式の ように定式化される。

$$
\begin{array}{ll}
\min _{\rho \in \mathbf{L}}[C(\rho)], & C(\rho)=\mathbf{d}^{T} \mathbf{K d} \\
\mathbf{L}=\left\{\rho \mid 0 \leq \rho_{i} \leq 1 \quad(i=1, \cdots, N), \quad \sum_{i=1}^{N} \rho_{i} \leq m_{S}, \quad G(\rho) \geq \bar{G}\right\}
\end{array}
$$

ここに, $\rho$ は各要素の密度比 $\left\{\rho_{1}, \rho_{2}, \cdots, \rho_{N}\right\}$ で, その他の変数は(5) 式と同じである。ただし密度法では, 全体剛性マトリックス $\mathbf{K}$ は， 要素密度比の関数として次のように表される。

$$
\mathbf{K}(\rho)=\AA_{i=1}^{N}\left(\rho_{i}^{p} \mathbf{K}^{e i}\right)
$$

ここに, A は要素剛性マトリックスの重ね合わせを表す記号, $\mathbf{K}^{e i}$ は $i$ 番目要素の剛性マトリックスである。また， $p$ はべき乗係数 で，本論文では文献 19)にしたがい $p=2$ とする。また，重力制御 関数 $G$ は(3)式と同様に次式で定義される。

$$
G(\rho)=\sum_{i=1}^{N} g_{i}(\rho) / \sum_{i=1}^{N} m_{i}
$$

ここに， $g_{i}$ の定義は(4)式と同じであるが， $m_{i}$ は $i$ 番目の要素と面 を共有する要素で，内部の要素では 6 ，端や隅の要素ではそれ以 下となる。

\section{2 最適性規準法による解法}

(31)式を最適性規準法によって解く。まず, 設計変数を次式のよ うに $\rho$ から $\alpha(=1-\rho)$ に変更する。

$$
\begin{aligned}
& \min _{\alpha \in \mathbf{L}}[C(\alpha)], \quad C(\alpha)=\mathbf{d}^{T} \mathbf{K d} \\
& \mathbf{L}=\left\{\alpha \mid 0 \leq \alpha_{i} \leq 1 \quad(i=1, \cdots, N), \quad \sum_{i=1}^{N}\left(1-\alpha_{i}\right) \leq m_{S}, \quad G(\alpha) \geq \bar{G}\right\}
\end{aligned}
$$

ただし， $\rho_{i}=\left(1-\alpha_{i}\right), i=1, \cdots, N$ である。このような変更により,(34) 式は(5)式の穴の寸法を等しくして，この穴の寸法を設計変数にす ることに対応する（ただし，均質化法では，弾性定数は密度のべ き乗関数にはならない)。最適性規淮法の場合, 重力制御関数の制 約との関係から設計変数をこのように設定する方がフィルタリン グの効率が良い。

(34)式の Lagrangian は次式となる。

$$
L(\alpha)=C(\alpha)-\Lambda\left(\sum_{i=1}^{N}\left(1-\alpha_{i}\right)-m_{s}\right)-\Lambda_{g}(\bar{G}-G(\alpha))
$$

次に, (35)式を設計変数とラグランジェ乗数に関して変分をとるこ とにより

$$
\begin{aligned}
& \delta L(\alpha)=\sum_{i=1}^{N}\left(\frac{\partial C(\alpha)}{\partial \alpha_{i}}+\Lambda+\frac{\partial G(\alpha)}{\partial \alpha_{i}} \Lambda_{g}\right) \delta \alpha_{i} \\
& -\left(\sum_{i=1}^{N}\left(1-\alpha_{i}\right)-m_{s}\right) \delta \Lambda-(\bar{G}-G(\alpha)) \delta \Lambda_{g}=0
\end{aligned}
$$

(12)式と同様に, (36)式の $\delta \alpha_{i}(i=1, \cdots, N), \delta \Lambda, \delta \Lambda_{g}$ の任意性から次式 の最適性規準を作ることができる。

$$
\begin{aligned}
& \alpha_{i}^{(k+1)}=\left[\frac{\Lambda^{(k)}+\frac{\partial G\left(\alpha^{(k)}\right)}{\partial \alpha_{i}^{(k)}} \Lambda_{g}^{(k)}}{\left.\frac{\partial C\left(\alpha^{(k)}\right)}{\partial \alpha_{i}^{(k)}}\right]^{\beta} \alpha_{i}^{(k)} \quad(i=1, \cdots, N)}\right. \\
& \Lambda^{(k+1)}=\left[\frac{1}{m_{S}} \sum_{i=1}^{N}\left(1-\alpha_{i}^{(k)}\right)\right]^{\beta} \Lambda^{(k)}, \quad \Lambda_{g}^{(k+1)}=\left[\frac{\bar{G}}{G\left(\alpha^{(k)}\right)}\right]^{\beta} \Lambda_{g}^{(k)}
\end{aligned}
$$


また， $\alpha_{i}, \Lambda, \Lambda_{g}$ には次式の制約条件

$0 \leq \alpha_{i} \leq 1 .(i=1, \cdots, N), \quad \Lambda \leq 0, \quad \Lambda_{g} \leq 0$

があるので, (37)〜(39)式より次式の最適性規準が得られる。

$$
\begin{aligned}
& \alpha_{i}^{(k+1)}=\min \left\{\max \left\{0, s_{i}^{(k)}\right\}, 1\right\} \\
& \Lambda^{(k+1)}=\min \left\{0,\left[\frac{1}{m_{S}} \sum_{i=1}^{N}\left(1-\alpha_{i}^{(k)}\right)\right]^{\beta} \Lambda^{(k)}\right\} \\
& \Lambda_{g}^{(k+1)}=\min \left\{0,\left[\frac{\bar{G}}{G\left(\alpha^{(k)}\right)}\right]^{\beta} \Lambda_{g}^{(k)}\right\}
\end{aligned}
$$

ここに,

$$
s_{i}^{(k)}=\left[\frac{\Lambda^{(k)}+\frac{\partial G\left(\alpha^{(k)}\right)}{\partial \alpha_{i}^{(k)}} \Lambda_{g}^{(k)}}{\frac{\partial C\left(\alpha^{(k)}\right)}{\partial \alpha_{i}^{(k)}}}\right]^{\beta} \alpha_{i}^{(k)}
$$

均質化設計法の場合と同様に, (41)式には, 設計変数の変動幅の制 約を課す。また, $\Lambda, \Lambda_{g}$ は最適化繰返し計算の各ステップの内側の ループでも収束計算を行う。

なお, 平均コンプライアンス $C$ の設計変数 $\alpha_{i}$ 関する感度係数は 次式のように求められる。

$$
\begin{aligned}
\frac{\partial C}{\partial \alpha_{i}} & =-\mathbf{d}^{T} \frac{\partial \mathbf{K}}{\partial \alpha_{i}} \mathbf{d}=-\mathbf{d}^{e i^{T}} \frac{\partial\left(\left(1-\alpha_{i}\right)^{p} \mathbf{K}^{e i}\right)}{\partial \alpha_{i}} \mathbf{d}^{e i} \\
& =\mathbf{d}^{e^{i} T}\left(p\left(1-\alpha_{i}\right)^{p-1} \mathbf{K}^{e i}\right) \mathbf{d}^{e i}
\end{aligned}
$$

\section{4. 解析例}

\section{1 パラメータの設定}

最適性規準法では，以下のパラメータの設定が必要である。

1) (19)-(22),(42)-(44)式のべき乗係数 $\beta$

2) 設計変数の変動幅の制約值（move limit） $\zeta$

3) 感度係数を更新する外側ループの繰り返し回数

4) 感度係数を更新しない内側ループの繰り返し回数

以上のパラメータを決定するために, 4.2 節に示す例題で数值実験 を行った。まず，1)と 2)の $\beta, \zeta$ は，いずれも設計変数の変動幅を 制約するものである。 4.2 節に示すフィルタリングを除いた例題で 調査した結果， move limit を設けない場合は $\beta$ が 0.25 以下で妥当 な解が得られることがわかった。そこで， $\beta$ は 0.25 に設定し， $\zeta$ に関して調查したところ同じ例題では 0.1 の近傍で最小の平均コ ンプライアンスが得られた。そこで,ここでは $\zeta=0.1$ に設定した。 次に，3)の感度係数を更新する外側のループの繰り返し回数は, 30 回程度で平均コンプライアンスの值がほぼ一定になる。しかし， この段階では設計変数等は(8)-(11)の最適性規淮を満足していない ため, ここから move limit $\zeta を \zeta^{(k+1)}=\zeta^{(k)} / 1.1^{(k-29)} \quad(k=30,31, \cdots)$ として絞り込みトータル 40 回まで繰り返すこととした。また, 感 度係数の計算をしない内側のループは，100 回程度で質量制約が アクティブになる（制約值に等しくなる）。しかしながら，重力制 御関数值を各ステップでアクティブにすると，この制約が敏感に 効きすぎて，最適解から大きく外れてしまう。したがって， $\Lambda_{g}$ の 更新は質量制約に比較して少なくする必要がある。そこで，本プ
ログラムでは， $\Lambda$ に関する更新は 100 回， $\Lambda_{g}$ に関する更新は 5 回に設定した。

\section{2 均質化設計法による解析例}

均質化設計法におけるフィルタリングの効果を示すために 2 次 元問題の解析例を示す。有限要素としては，せん断剛性に関して 低減積分を行った 4 節点アイソパラメトリック要素を用いる。

まず，既往の文献によく引用されている 図4に示すような MBB はり ${ }^{9,18)}$ の解析例を示す。解析は対称性を利用して $1 / 2$ 領域で行い, 有限要素分割は, この領域で $75 \times 25$ とした。総密度比の制約値は $m_{S} / N=0.5$ （全密度比を 1 とした場合の $50 \%$ ）とした。なお，弾 性マトリックスは平面応力問題のものを用いている。

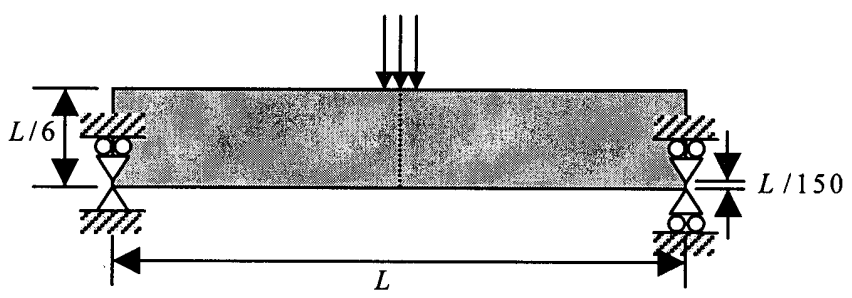

図 4 MBB はりモデルのトポロジー解析領域

図 5 は, フィルタリングの効果を示すために, 重力制御関数の 制約値 $\bar{G}$ を変化させた場合の結果を示している。図中の $G$ は最適 解における重力制御関数値, $\bar{m}$ は最適解における総密度比の比率,

$$
\bar{m}=\sum_{i=1}^{N}\left(1-a_{i} b_{i}\right) / N
$$

である。また， $C / C_{0}$ は，フィルタリングをかけた場合の平均コ ンプライアンス值を, $\bar{G}=0$ の場合の平均コンプライアンス值 $C_{0}$ との比で示したものである。なお, 図ではグレースケールのフィ ルタリング効果も示すため, 密度比のしきい值を 0.1 とし, それ 以下の要素は除いている。図からわかるように, 重力制御関数值 を制約しない場合（ $\bar{G}=0 ）$ は，チェッカーボード状の密度分布 が現れ，どこをどうつなげばよいかはっきりしない。これに対し て, 制御関数の制約值が 0.8 以上の場合は非常にはっきりした位 相が得られ，設計者に明確な情報を与えることができる。また， 制約值が 0.8 以上では, 平均コンプライアンス值が徐々に高くな り最適解からは外れるが, 構造のシンプルさが要求され, どこか の部材を省く必要がある場合には,このような位相が利用できる。 なお, 図 $5(\mathrm{c})(\bar{G}=0.85)$ で, (b)の解 $(G=0.87)$ が得られない のは, 局所解に収束しているためと考えられる。

図 6 は $\bar{m}_{S}\left(=m_{S} / N\right)$ を $0.3,0.4,0.5,0.6$ に変化させた場合の解 析結果 (全体図) を示している。ただし, 重力制御関数の制約值 $\bar{G}$ は, 解の平均コンプライアンス值が, 制約しない場合と比較して 大きく変化しない範囲で定めている。また, 図では, 密度比のし きい值は 0.3 とし, それ以下の要素は除いている（実用的にはこ の程度のしきい值を設定すればよい)。図からわかるように, どの $\bar{m}_{S}$ に対しても非常に明解な位相が得られており, 本論文で示した フィルタリング法が有効であることがわかる。なお, 重力制御関 数の制約值は，まず，制約なしの場合を計算し，それから 0.05〜 0.1 程度上げた值で制約すれば, 平均コンプライアンス值を大きく 上げることなく，しかも鮮明な位相が得られる。 


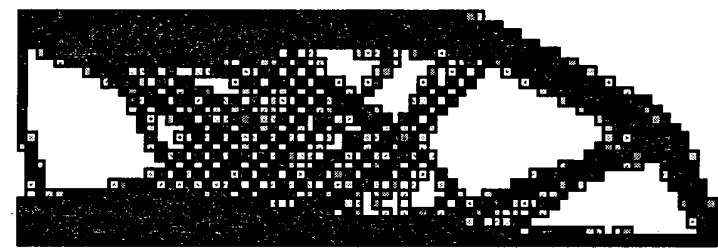

(a) $\bar{G}=0, \quad G=0.73, \quad \bar{m}=0.50$

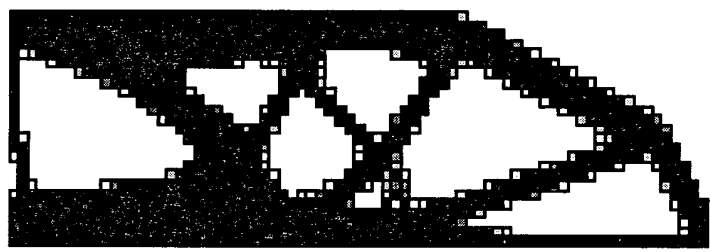

(b) $\bar{G}=0.8, \quad G=0.87, \quad \bar{m}=0.50, \quad C / C_{0}=1.02$

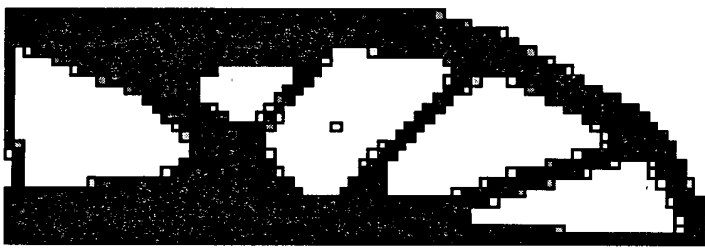

(c) $\bar{G}=0.85, \quad G=0.89, \quad \bar{m}=0.50, \quad C / C_{0}=1.08$

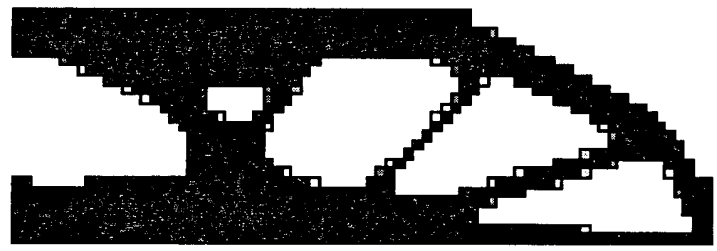

(d) $\bar{G}=0.90, \quad G=0.90, \quad \bar{m}=0.50, \quad C / C_{0}=1.18$

図 $5 \mathrm{MBB}$ はりの最適位相（ $\bar{G}$ を変化させた場合）

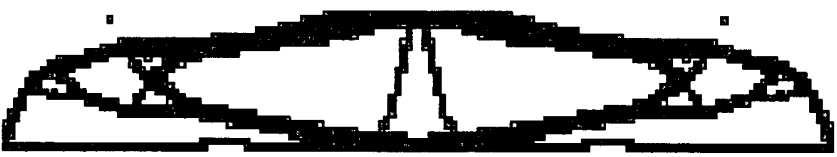

(a) $\bar{m}_{s}=0.3, \bar{m}=0.30, \bar{G}=0.85, \quad G=0.85, \quad C / C_{0}=1.05$

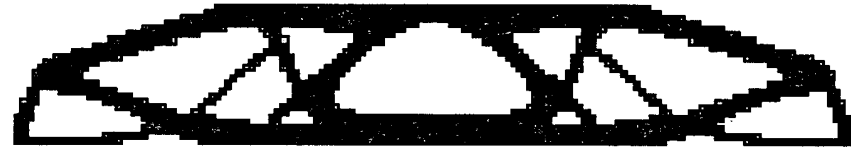

(b) $\quad \bar{m}_{s}=0.4, \quad \bar{m}=0.40, \quad \bar{G}=0.85, \quad G=0.87, \quad C / C_{0}=1.08$

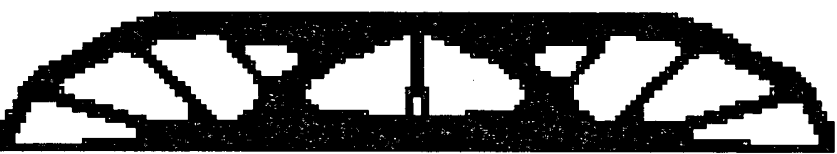

(c) $\quad \bar{m}_{s}=0.5, \quad \bar{m}=0.50, \bar{G}=0.85, \quad G=0.89, \quad C / C_{0}=1.08$

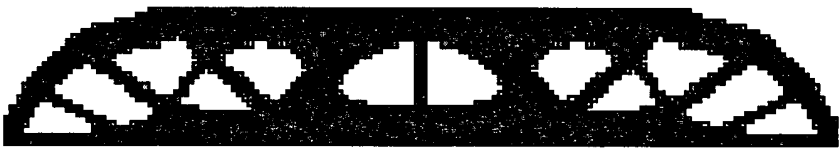

(d) $\bar{m}_{s}=0.6, \quad \bar{m}=0.60, \quad \bar{G}=0.8, \quad G=0.89, \quad C / C_{0}=1.03$

図 $6 \mathrm{MBB}$ はりの最適位相（ $\bar{m}_{S}$ を変化させた場合）

4.3 密度法による解析例

次に，密度法におけるフィルタリングの効果を示す。密度法に
よる位相最適化に用いる有限要素としては, 関口と菊池 ${ }^{20}$ が提案 している応力仮定法にもとづく 8 節点長方柱要素を採用する ${ }^{12)}$ 。 また，本プログラムでは大規模計算が可能となるように連立方程 式の解法として Element-by- Element 法にもとづく前処理付共役勾 配法 ${ }^{21)}$ を用いている。この方法では，通常のパソコンのメモリ 256Mbyte 内で， 50 万要素程度までの解析が可能である ${ }^{12)}$ 。なお， 密度法では, 要素形状が等しい場合, 要素剛性マトリックスの再 計算の必要がなく，共役勾配法の計算効率が非常に良い。

まず，4.2節に示した MBB はりの例題をソリッド要素で解析し た例を示す。要素分割数は $75 \times 25 \times 1$ とし, 総密度比の制約値は $\bar{m}_{s}=0.5$ としている。図 7 は, フィルタリングの効果を示すため に，重力制御関数の制約值 $\bar{G}$ を变化させた場合の結果を示してい る。なお， 3 次元問題の位相表示は複雑であるため,ここでは, Open-GL を用いて作成したグラフィックスソフトにより結果を表 示している。このためグレースケールの表示はしていない。また， 密度比のしきい值は 0.3 としている。図からわかるようフィルタ リングをかけない場合（ $\bar{G}=0 ）$ は，均質化設計法による解より もさらに顕著にチェッカーボード状の密度分布が現れる。しかし， $\bar{G}$ が, 0.75 の場合は図 5 の(b) と, 0.8 の場合は図 5 の(c), (d) と類似 した位相が得られている。また, 総密度比 $\bar{m}$ はすべての場合で制 約值に一致している。

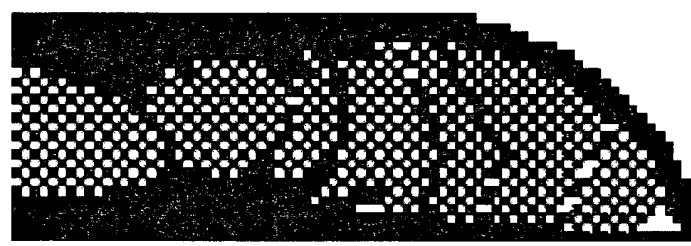

(a) $\bar{G}=0, \quad G=0.61, \quad \bar{m}=0.50$

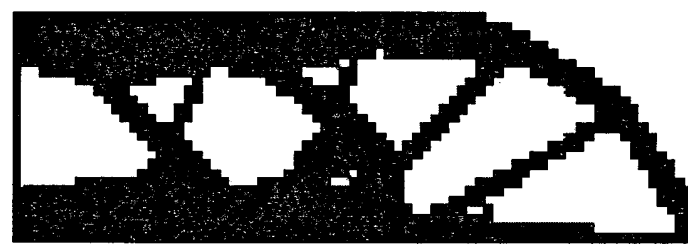

(b) $\bar{G}=0.75, \quad G=0.84, \quad \bar{m}=0.50, \quad C / C_{0}=1.04$

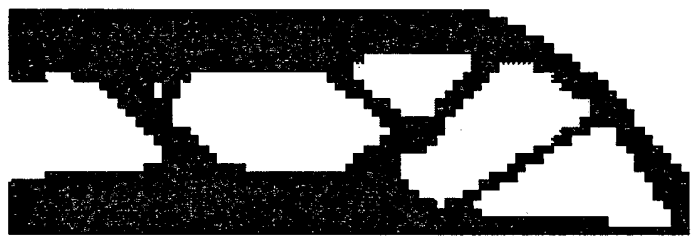

(c) $\bar{G}=0.8, \quad G=0.88, \quad \bar{m}=0.50, \quad C / C_{0}=1.21$

図 7 密度法による MBB はりの解析結果

図 8 は $\bar{m}_{S}\left(=m_{S} / N\right)$ を $0.3,0.4,0.5,0.6$ に変化させた場合の解 析結果 (全体図)を示している。ただし，重力制御関数の制約值 $\bar{G}$ は,チェッカーボード分布がほぼ消える值に設定している。また, 図では, 密度比のしきい值は 0.3 とし, それ以下の要素は除いて いる。図において， $\bar{m}_{s}=0.3$ の場合で， $\bar{G}$ と $C / C_{0}$ の值が大きく なっているのは, 総密度比が小さい問題では, チェッカーボード 状の複数の要素で面的に（薄板として）剛性を高める方が構造上 
有利になるため, 接合部付近のチェッカーボードが消えにくいこ とに起因する。図より, 図 6 の均質化設計法の結果に比較すると 形態変化の自由度の点で劣るが, フィルタリングの効果により密 度法においてもそれなりに明確な位相が得られることがわかる。

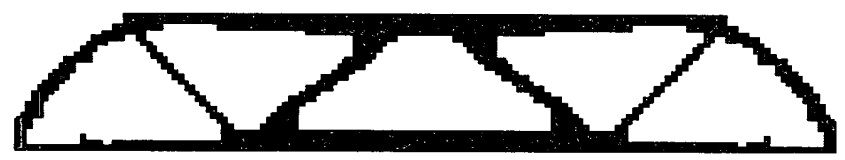

(a) $\bar{m}_{s}=0.3, \quad \bar{m}=0.30, \quad \bar{G}=0.9, \quad G=0.89, \quad C / C_{0}=1.49$

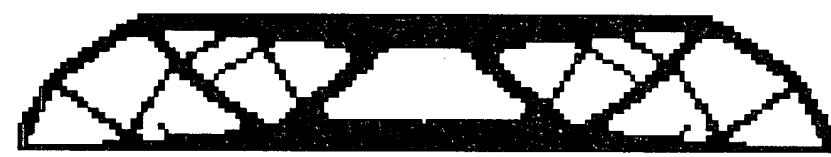

(b) $\quad \bar{m}_{s}=0.4, \quad \bar{m}=0.40, \quad \bar{G}=0.80, \quad G=0.86, \quad C / C_{0}=1.10$

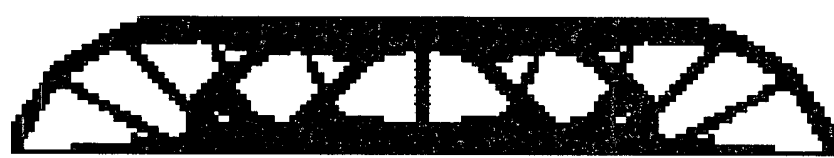

(c) $\bar{m}_{s}=0.5, \quad \bar{m}=0.50, \quad \bar{G}=0.75, \quad G=0.84, \quad C / C_{0}=1.04$

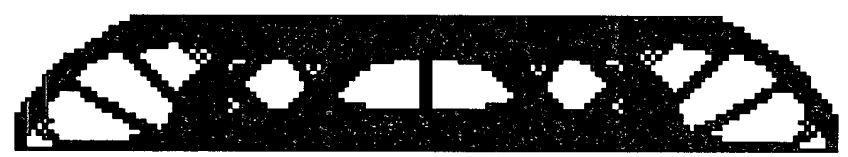

(d) $\bar{m}_{s}=0.6, \quad \bar{m}=0.60, \quad \bar{G}=0.75, \quad G=0.84, \quad C / C_{0}=1.02$

図 8 密度法による $\mathrm{MBB}$ はりの最適位相 $\left(\bar{m}_{S}\right.$ を変化させた場合)

4. 4 コンクリートラーメンの解析例

建築的な例題として，1 層コンクリートラーメンを想定した例 題を解析する。設計領域は図 9 に示すものとし, 荷重は鉛直等分 布荷重と鉛直荷重の 0.2 倍の水平等分布荷重を加える。底面の支 持部は, 柱脚に相当する部分 $(50 \mathrm{~cm} \times 50 \mathrm{~cm})$ のみを完全固定とす る。また, 図の梁部分 $(50 \mathrm{~cm} \times 50 \mathrm{~cm})$ の設計は固定し, 梁を除い た部分を設計対象とする。設計領域の寸法は図中に示すように, アスペクト比を変化させた 3 種の場合について解析する。材料は コンクリートとし，ヤング係数は $20.6 \mathrm{GPa}$ ，ポアソン比は $1 / 6$ とし ている。解析は密度法による 3 次元解析法によって行い, それぞ れの場合の有限要素分割数は, Case 1 が $60 \times 5 \times 40$, Case 2 が 40 $\times 5 \times 40$, Case 3 が $40 \times 5 \times 60$ とする。また, 総密度比の制約值 $\bar{m}_{S}$ は 0.2 に設定する。なお, 本例題は応力分布が非対称となるため, プログラム内で設計変数を設計領域中心の $x z$ 面に対して対称と なるように設定している。

重力制御関数の制約值に関しては，0.8から 0.1 づつ順に上げて 調査した結果，制約值 0.8 および 0.9 では，指定した制約値を満足 せず，最終解にチェッカーボード分布が見られた。これは，この 問題の場合，荷重が分布荷重であるため，構造的に面（板）構造 が現れやすいことが原因と考えられる。この対策としては， $\Lambda_{g} に$ 関する内側ループの繰り返し回数を増やすことと, 重力制御関数 の制約の影響を高めるため制約值をさらに上げることが考えられ る。しかし，内側ループの繰り返し回数を増やすと総密度の制約 が満足されなくなるため, ここでは, 後者の方法を採用し, 重力 制御関数值を，実際には制約が満足されない 1.1 に設定した。
図 10,11,12 は，Case1〜Case3について，以上の設定にしたがっ て解析した結果を, 2 次元図と透視図で示している。なお, 密度 比のしきい值は 0.3 としている。これらの図からわかるように, チェッカーボード分布が一部残っているものもあるが, 重力制御 関数値の制約値を高めに設定することで, 設計者に明解な情報を 与えることのできる位相が求まっている。なお, 図には最適解の 総密度比と重力制御関数值が示されているが, 総密度比はほぼ制 約值と一致しており，質量制約は乱されていないことがわかる。

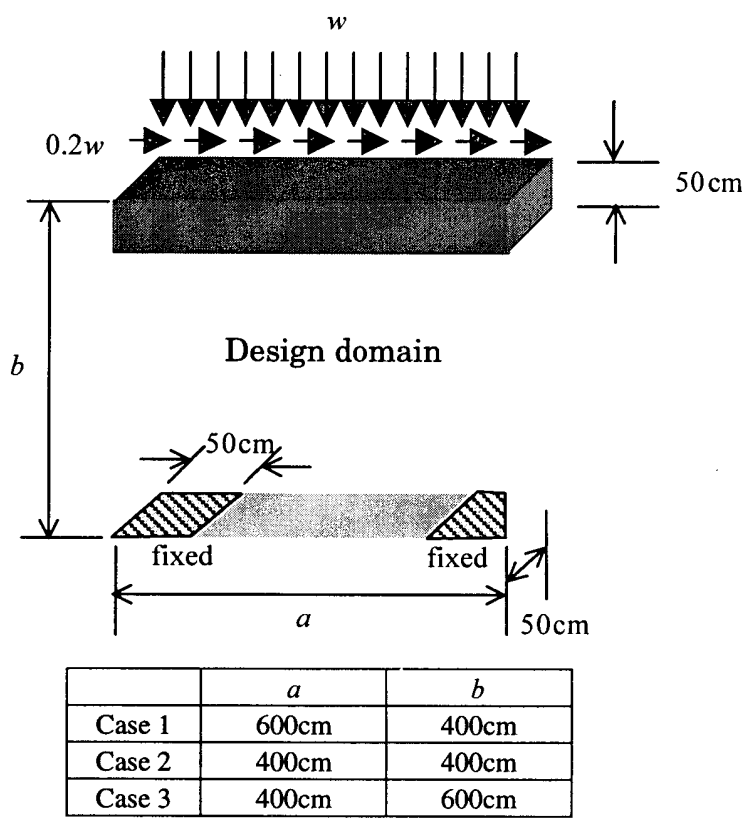

図 9 コンクリートラーメン構造を想定した設計領域

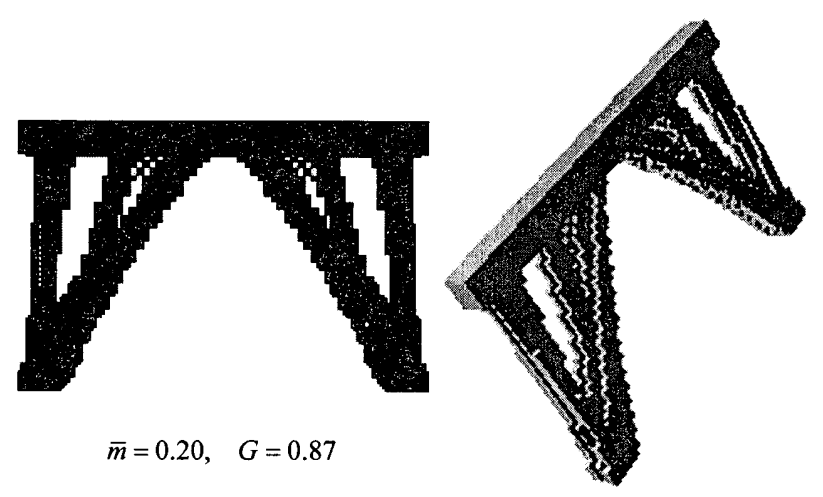

図 10 コンクリートラーメンの最適位相（Case1）
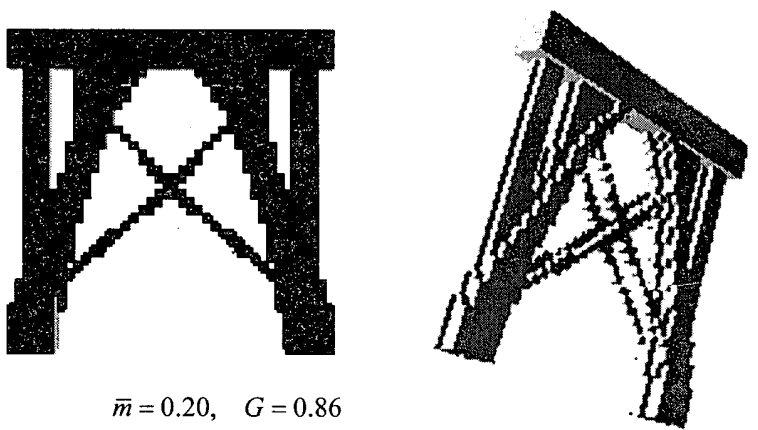

$\bar{m}=0.20, \quad G=0.86$

図 11 コンクリートラーメンの最適位相（Case2） 

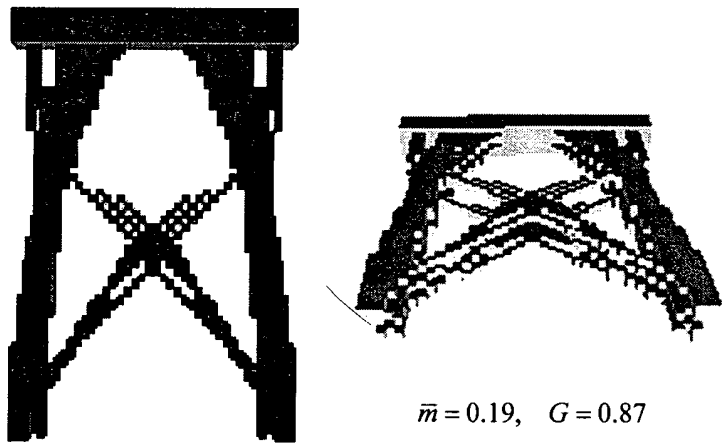

図 12 コンクリートラーメンの最適位相（Case3）

\section{5.まとめ}

本論文では，均質化設計法および密度法によって定式化された 位相最適化問題を最適性規淮法を用いて解く場合に有効となるフ イルタリング法の提案を行った。本フィルタリング法は, 要素の 周辺にソリッドまたは空隙を集中させる重力制御関数を最適化問 題の制約条件として制御するものであり，最適解に頻繁に現れる チェッカーボード状の密度分布を防ぎ，よりシンプルで明解な位 相を求めることができる。

本方法の有効性を MBB はりの例題を解析することによって検 討した結果, 均質化設計法による 2 次元解析では, 重力制御関数 値を制約することでチェッカーボード状の密度分布が消え，さら にその制約值を高くすることによって, よりシンプルな形態が得 られることがわかった。また, 密度法による 3 次元解析において も, フィルタリングの効果は均質化設計法の場合と同様に有効で あることがわかった。

次に, 密度法による解法を利用して, コンクリートラーメンを 想定した例題を解析した結果，分布荷重を受ける例題では，チェ ッカーボード状の密度分布が現れやすく, 重力制御関数值の制約 と総密度比の制約を同時に満足する解が得られなかった。しかし， このような場合でも, 重力制御関数值を 1 以上の高い值に設定す ることで, チェッカーボード状の密度分布が少ない明解な位相を 得ることができた。

謝辞 : 本研究を遂行するにあたり, 平成 12 年度科学研究費（基盤 研究(c)(2)）の補助を受けた。琍くいんとの石井恵三氏, 江島晋氏 より貴重な助言を頂いた。また, 東京大学工学部船舶海洋工学科 卒論生小玉浩平君に 3 次元位相を表示するプログラムを作成して 頂いた。ここに記して謝意を表します。

\section{参考文献}

1）大森博司，鬼頭伸彰：遺伝的アルゴリズムを用いたトラス構造物の形態 創出, 日本建築学会構造系論文集, No.520, pp.85-, 1999.6

2）鈴木謙仁, 大森博司, 張奕: :ESO 法による構造物最適化問題の解析（そ の 1 : 応力を基準とした場合), 日本建築学会大会梗概集, B-1 分冊, pp.387-388, 1999

3) 張奕, 大森博司, 鈴木謙仁: ESO 法による構造物最適化問題の解析（そ の 2 : 变位制限下における解析), 日本建築学会大会梗概集, B-1 分冊, pp.389-340, 1999
4) 本間俊雄, 登坂宣好, 角 広幸 : 自律分散アプローチによる逆問題の計 算法一自律分散有限要素法の提案と応用一, 日本建筑学会構造系論文集 NO.526, pp.69-76, 1999.12

5）本間俊雄，登坂宣好：セル・オートマトンの節点近傍モデルを用いたト ポロジー最適化，計算工学講演会論文集，Vol.5, pp.441-444, 2000

6) K. Maute and E. Ramm : Adaptive Topology Optimization of Shell Structures, AIAA Journal, Vol.35, No.11, 1997

7) E. Ramm, K. Maute, S. Schwarz : Conceptual design by structural optimization. In: R. de Borst., N. Bicanic, G. Mechke (eds) Conference Proceedings of EURO-C 1998, Badgastein, Austria, pp.879-896, Balkema, Rotterdam, 1998

8) 藤井大地, 松本慎也, 藤谷義信, 菊池昇 : グランドストラクチャー法に よる骨組構造物の位相最適化, 日本建築学会構造工学論文集, Vol.46B, pp.1-8, 2000

9）藤井大地，菊池昇：SLP 法を用いたトポロジー最適化における数值的不 安定の改善，日本建築学会構造系論文集，No.521，pp.65-72，1999.7

10) D. Fujii, N. Kikuchi : Improvement of numerical instabilities in topology optimization using the SLP method, Structural Optimization, Vol.19, pp.113-121, 2000

11）藤井大地，菊池昇 : 均質化法によるシェル構造の形状とトポロジーの同 時最適化，日本建築学会大会梗概集，B-1，pp.383-384，1999

12）藤井大地，鈴木克幸，大坪英臣 : ボクセル有限要素法を用いた構造物の 位相最適化，日本計算工学会論文集，Vol.2，pp.87-94，2000

13) K. Maute and E. Ramm : Adaptive topology optimization, Structural Optimization, Vol.10, pp.100-112, 1995

14) O. Sigmund and J. Petersson : Numerical instabilities in topology optimization: A survey on procedures dealing with checkerboards, mesh-dependencies and local minima, Structural Optimization, Vol.16, pp.68-75, 1998

15) M. P. Bendsøe and N. Kikuchi : Generating Optimal Topologies in Structural Design using a Homogenization Method, Computer Methods in Applied Mechanics and Engineering, Vol.71, pp.197-224, 1988

16) K. Suzuki and N. Kikuchi : A homogenization method for shape and topology optimization, Computer Methods in Applied Mechanics and Engineering, Vol.93, pp.291-318, 1991

17) Bendsøe, M. P., Optimal shape design as a material distribution problem, Struct. Optimiz., 1, 193-202, 1989

18) Zhou, M. and Rozvany, G.I.N., The COC algorithm, Part II: Topological, geometrical and generalized shape optimization, Computer Methods in Applied Mechanics and Engineering, 89, 309-336, 1991

19) Yang, R.J. and Chuang, C.H., Optimal topology design using linear programming, Computers \& Structures, 52(2), 265-275, 1994

20) 関口美奈子, 菊池昇, 混合的な有限要素剛性マトリックスの導き方に関 する一考察ーClough 1960 年の論女を中心としてー, 計算工学講演会論 文集，4(1)，pp.131-134,1999

21）鈴木克幸分担執筆, 計算力学ハンドブック ( I 有限要素法構造編), 日 本機械学会, pp.23-31，1998

(2000年8月21日原稿受理，2000年12月14日採用決定) 